INTERNATIONAL BULLETIN OF BACTERIOLOGICAL NOMENCLATURE AND TAXONOMY

Volume 11 No. 1 January 15, 1961 pp. 13-16

\title{
ON CLASSIFICATION AND TAXONOMY OF DYSENTERY BACTERIA
}

E. D. Ravich-Birger, V. L. Troitski and V.D. Gekker

State Control Institute of Medical and Biological Preparations, and Institute of Epidemiology and Microbiology, Academy of Medical Sciences of the USSR, Moscow

SUMMARY: Here are listed the reasons determining the Soviet classification of the dysentery bacteria and the major differences from the International Schema of the International Subcommittee on Enterobacteriaceae. The Soviet arrangement is based on typospecific antigens irrespective of group variations of antigens.

\section{Peзюме .}

В статье приведены обоснования, положенные в основу советской классио̆икации тизентерийых бактерий. Проводится сопоставление иекдународной и вре менной советской схемы. Вносится предломение об

установлении эталонов типовых культур по типоспецич̆ическому антигену, независим от вариаций груп повых антигенов, а также о совместной проработке принципиальных установок для построения классификационных схем.

It has been pointed out by W.H. Ewing et al. (1959) that the comprehension of publications on dysentery microbes by soviet students is impeded by the discrepancies in the nomenclature. This is due to some divergencies of the soviet classification schemes of Shigellae from the international one.

According to Soviet classification, the genus of dysentery microbes (Shigella) is divided into 4 species:

$$
\begin{aligned}
& \text { S. grigoriewa-Shigae } \\
& \text { S. } \frac{\text { stutzeri-schmitzii }}{\text { S. flexneri }} \\
& \text { ․․․ } \text { sonnei }
\end{aligned}
$$


This classification is based on biochemical, enzymatic and serological differences between the species. Some of these species contain certain varieties which are grouped into subspecies and types. Thus, bacteria of the GrigorievaShigae species include varieties (subspecies) discovered by Novgorodskaya and Semenova. These students had no opportunity to compare their strains with the foreign ones. It is well known at the present that the Novgorodskaya-Semenova strains are identical to those of Large-Sachs.

The first and second species of the soviet classification are included in the subgroup $A$ of the classification of the International Shigella Center. The numeration suggested by this classification, from 1 to 10 , includes in the same series both the independent Grigorieva-Shiga or the StutzerSchmitz species and the Large-Sachs varieties (or Novgorodskaya-Semenova). While the former have apparently stabilized during evolution and have fairly constant clear cut characteristics, the Large-Sachs varieties are not at all as constant and their number is by no means confined to those already described. While it is possible and advisable to conceive the Grigorieva-Shiga and Stutzer-Schmitz bacteria as independent species there are no grounds to consider the various serological types of Large-Sachs bacteria as individual species. Hence, in the soviet nomenclature the subgroup A corresponds to two species of dysentery bacteria, viz. Shigella grigoriewa-shiga and S. stutzeri-schmitzii and by the variants described by Large, Sachs, and in the Soviet Union by Novgorodskaya and Semenova which are regarded as varieties of $\underline{\mathrm{S}}$. grigoriewa-shigae.

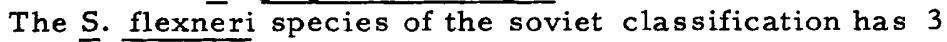
subspecies, viz. the correct Flexner, Newcastle and BoydNovgorodskaya names. According to the international classification they correspond to the $B$ and $C$ subgroups. As pointed out by Ewing previously in 1949, these microbes have biological characters in common and are probably variants of bacteria of the $S$. flexneri species. However due to their antigenic and immunological heterogeneity they have to be isolated into several subspecies, two of which-proper Flexner and Boyd-Novgorodskaya-are divided into types which are cross related within the subspecies but mostly have a marked type-specific antigen. It does not seem expedient to produce an unlimited number of standard types by introducing numerous variants which have lost or restores some 
group antigen. One should dispose of standards according to the type-specific antigen, that is to say the type should be represented by strain $3 b$ as the most complete one or by $4 b$ or la, etc. If we accept such a relatively constant set of type cultures as standards we shall be able to compare the types of the soviet nomenclature with those of the International Center. It appears from a comparison of the evidence obtained by Novgorodskaya (1959) and W.H. Ewing et al. (1959) that a comparative study by different workers does not show identity thorughout all types. This is due to excessive details of the antigenic composition and high variability of the group antigens. It seems necessary to establish for the type strains of $\mathbf{S}$. flexneri a correspondence of typespecific antigens as the criterion for identification.

Our opinion is corroborated by the case of the BoydNovgorodskaya subspecies ( . boydii) in which the less differentiated antigenic structure enables one to demonstrate the coincidence of standard cultures in a greater number of cases.

One may agree completely with the division in the $B$ and

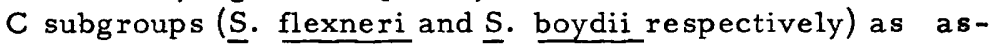
sumed in the international classification. Yet, there exists a not less isolated subgroup of bacteria included in the international classification under the title of Type 6 (S. newcastle) which however is a biochemically heterogeneous set of types whose antigenic and immunological properties are largely obscure.

This is reflected by the Soviet classification in which every subgroup occupies the position of a subspecies.

Subgroup D of the international classification corresponds to $S$. sonnei species of the Soviet classification.

Within $\underline{S}$. flexneri and $\underline{S}$. boydii subspecies one should accept the designation of the types by arabic figures as suggested by the international classification. This will facilitate mutual understanding in the analysis of studies from various countries.

The above considerations require further collaboration for treating some general fundamental principles which are necessary for the construction of uniform classification schemes. 
Page 16

INTERNATIONAL B ULLETIN

\section{REFERENCES}

Ewing, W.H. 1949. J. Bact. 78(6):33.

- Jane G. Johnson and Betty R. Davis. 1959. A comparison of the Shigella classification usedinthe U.S.S.R. with the International Shigella Schema. Internl. Bull.

Bact. Nomen. and Taxon. 9(4):177-181.

Grigoriev, A.V. 1891. On microorganisms in dysentery.

Voenno Meditsinskii Zhurnal. 7:73.

Novgorodskaya, E.M. 1959. Zhürnal Mikrobiologii i

Epidemiologii. No. 4 p. 9. and O. A. Semenova. 1948. Trudy Leningradskogo

Instituta Epidemiologii i Microbiologii, L. X:76-95.

Troitski, V. L. 1953. Zhurnal Mikrobiologii i Epidemiologii. No. 3 p. 7. 